\title{
O PRETÉRITO PERFEITO COMPOSTO EM PORTUGUÊS: UMA ANÁLISE DE FUNÇÕES E VALORES MARCADOS PELA LEITURA ITERATIVA OU DURATIVA
}

\author{
THE COMPOUND PAST TENSE IN PORTUGUESE: ANALYSIS OF FUNCTIONS \\ AND VALUES MARKED BY ITERATIVE OR DURATIVE READING
}

\section{Diana Reis Bittencourt | Lattes | diana.bittencourt@ifc.edu.br ${ }^{1}$ Colégio Militar do Exército em Curitiba}

Resumo: Neste estudo, discutimos a semântica do pretérito perfeito composto (PPC), a partir das leituras de pluralidade que nele se pode obter, distribuídas em iterativa ou durativa, em razão da característica de cada predicado verbal. Apontamos ainda que essas leituras afastam o PPC de uma competição funcional com o pretérito simples na sincronia, refletindo uma situação linguística divergente da diacrônica, em que o pretérito composto alcançava valores que se aproximavam mais da expressão do pretérito simples. Assim, a contribuição da análise não está na investigação e apontamento das diferentes funções das duas formas de pretérito, mas sobretudo em retratar a caracterização semântica do PPC contemporâneo também como resultado da competição funcional entre as diferentes leituras do PPC ao longo de sua história: a leitura resultativa e as leituras de pluralidade que foram se estabelecendo em sua trajetória, conforme descreve Becker (2016). Do mesmo modo, a discussão proposta busca contribuir destacando a complexidade em se traçar uma definição única e rigorosa para esse tempo verbal. Dessa forma, buscamos desenvolver uma análise qualitativa com enfoque semântico, que toma como fundamentação principal a descrição de Ilari (2001) para esse tempo verbal e situa ainda as definições do perfeito a partir de Comrie (1976), Klein (1992) e Kiparsky (2005). Para tanto, os dados do Corpus do Português (CdP) são utilizados como um recurso para identificarmos as várias leituras do PPC. Nessa perspectiva, justifica-se a incompletude de descrições a partir de um valor semântico único para o PPC, posto que esse se configura de modo diferente em cada predicado que transita, de forma similar a uma expressão de quantificação. Por fim, a partir dessa caracterização semântica, propomos possíveis funções discursivas para a forma, em razão da repetição inferida na expressão do evento denotado pelo PPC. Como apontamento final, sublinhamos a forte presença da leitura durativa associado ao PPC a partir do século XIX, que pode ter sido o fator decisivo no afastamento das funções entre as formas simples e compostas de pretérito, o que está de acordo também com os resultados de Becker $(2016,2020)$ e Barbosa (2008).

Palavras-chave: Pretérito perfeito composto. Funções. Valores semânticos. Leitura iterativa. Leitura durativa.

\footnotetext{
${ }^{1}$ Lotada originalmente no Instituto Federal Catarinense, atua como docente civil de carreira EBTT no Colégio Militar do Exército em Curitiba.
} 
Abstract: In this study, we discuss the semantics of the compound past (perfect) (PPC), based on the plurality readings obtained in its usage and distributed in iterative or durative, due to the characteristic of each verbal predicate. We also pointed out that these readings deviate the PPC from a functional competition with the simple past in the synchrony, reflecting a linguistic situation divergent from the diachrony, in which the compound past tense reached values closer to the expression of the simple past tense. Thus, the contribution of the analysis does not concern an investigation pointing out the different functions of the two forms of past tense, but rather, it aims to show the semantic characterization of contemporary PPC also as a result of the functional competition between the different readings of PPC throughout its history: the resultative reading and the readings of plurality which were established in its trajectory, as described by Becker (2016). Also the proposed discussion seeks to contribute pointing out the complexity of formulating a single and rigorous definition of this verb tense. Therefore, we aim to develop a qualitative analysis on a semantic frame, based on Ilari (2001) as the main theoretical description and also points the definitions of the perfect from Comrie (1976), Klein (1992) and Kiparsky (2005. The data from the Corpus do Português (CdP) is used as a resource to identify the various readings of the PPC. In this perspective, the incompleteness of descriptions based in one semantic value for the PPC is justified, since it is configured differently in each predicate, similarly to a quantifier. Finally, from this semantic characterization, we propose possible discursive functions for the form, according to the repetition inferred in the event denoted by the PPC. As a final result, we highlight the frequent presence of the durative reading associated with the PPC from the 19th century, which might have been the decisive factor for the distancing of functions between the simple and compound forms of past tense, which is also similar to the results of Becker $(2016,2020)$ and Barbosa (2008).

Keywords: Compound past tense. Linguistic competition. Semantics. Iterative reading. Durative reading.

\section{Introdução}

O estudo de situações linguísticas em que uma potencial competição entre formas com valores semelhantes poderia ocorrer revela que as trajetórias que levam à variação e mudança linguística encontram distintas motivações ou restrições que afetam inclusive línguas com um mesmo ponto de origem, como as românicas. Assim, embora o uso das 
formas simples e compostas de pretérito em português pudesse configurar um possível cenário de variação em momentos anteriores da língua, o pretérito perfeito composto (PPC) alcançou especializações que limitaram o seu valor como durativo ou iterativo ao longo dos séculos, considerando-se a análise da forma numa perspectiva semântica que toma como ponto de partida Ilari (2001).

Nesta análise, tratamos de uma discussão voltada a valores semânticos e leituras do PPC, com destaque para o apontamento das principais leituras de pluralidade obtidas em seu uso, segundo Becker (2016), ou de pluracionalidade, a partir de Laca (2010) e Carvalho et al. (2010). Somam-se a essa análise qualitativa com enfoque semântico algumas definições em nível teórico que delineiam essas leituras do perfeito a partir das propriedades do predicado, bem como através da estrutura do evento e sua configuração tempo-aspectual, com base principal em Kiparsky (2002), mas também em Comrie (1976) e Klein (1992). Ainda assim, possíveis contextos diacrônicos em que pode ter havido sobreposição de valores com o pretérito perfeito simples (PPS) - que, brevemente, se diferencia pelo valor perfectivo e pela preferência à singularidade do fato, conforme Ilari (2001) - serão discutidos de modo sucinto, como por exemplo, em antigos contextos de uso em que o PPC aparecia antecedido pelo advérbio já, em dadas leituras que compõem usos já residuais atualmente, como mencionam Barbosa (2008) e Becker (2016).

Nessa perspectiva, o propósito principal é apontar que, apesar da possibilidade de uma direção inicial que promoveria uma competição maior entre as formas simples e compostas, o PPC seguiu um distinto percurso de evolução diacrônica, apresentado em Squartini e Bertinetto (2000). Em resumo, os autores, com base em Harris (1982), apontam que o pretérito composto em português não teria alcançado os mesmos estágios de evolução que outras formas compostas equivalentes nas línguas românicas principais, as quais passaram a expressar o aspecto perfeito (de relevância) e até funções aorísticas, chegando a suplantar as formas simples na expressão do passado, como em francês, romeno e italiano padrão do Norte. ${ }^{2}$ Em comum, o processo de gramaticalização dessas perífrases nas línguas românicas teria se iniciado em situações e contextos em que elas passaram por (re)interpretações resultativas, que depois conduziram a leituras de um perfeito de persistência ou iterativo (leitura e estágio em que o PPC em português estaria situado); até obterem uma função de perfeito de relevância atual, como seria o caso do pretérito composto em espanhol, conforme pode ser devidamente recuperado em Oliveira (2010)

\footnotetext{
${ }^{2}$ Na próxima seção, tratamos um pouco mais desse processo, assim como dos estágios de evolução de Harris (1982).
} 
e Laca (2010), no que tange especialmente às línguas ibero-românicas.

Contudo, além do valor iterativo, o PPC foi obtendo cada vez mais uma leitura durativa - que se estabelece em conjunto com os verbos de estado ${ }^{3}-$, principalmente a partir dos séculos XVIII e XIX, o que pode ter sido um dos fatores decisivos em seu trajeto final de distanciamento do PPS, no que tange à expressão do aspecto verbal. Nesse ponto, justifica-se a realização de uma análise semântica sobre a atribuição de um valor (iterativo ou durativo) para o PPC, também por ser um modo de investigar por que ele não seguiu o mesmo percurso de formas compostas similares em outras línguas. Além disso, com base em seu valor semântico atual, seria possível comparar o PPC com outras categorias, como a de certos quantificadores que, ao passo que interferem nos predicados em que transitam, também recebem interpretações distintas em razão de cada sentido composicional adquirido, a partir da analogia proposta por Ilari (2001). Em nosso estudo, isso mostra-se particularmente relevante na descrição de possíveis funções da forma verbal, pois pode se refletir em seus usos. Por exemplo, o emprego do $\mathrm{PPC}$ pode estar relacionado à maior força e ênfase que o falante busca dar a uma informação, visto que em seu emprego pode estar inferida uma repetição de subeventos, isto é, do evento em suas instâncias, como no exemplo a seguir:

(01) Sr. João nunca os viu? - Vi, vi, tenho visto muitos. Olhe que fazem coisas que, fora a alma, já se sabe. (CdP, PB, séc. XX) ${ }^{4}$

Esse dado selecionado em (01) é interessante também para ilustrar uma outra função discursiva que se aventa para o PPC, de que combinado com verbos de percepção direta serviria como um recurso de intensificação, pois indiretamente quantifica, pluraliza um evento em que se evidencia a fonte da informação. Isso ocorre pois, quando associada a verbos de percepção direta, como ver e ouvir, a ideia de pluralidade de subeventos embutida no evento denotado pode associar-se muito bem a uma possível necessidade do falante de garantir a fonte e a veracidade de sua informação, que não se baseia na ocorrência singular de um evento, mas em várias delas. Isso porque os verbos de percepção acabam revelando a fonte (supostamente verídica) da informação, de modo que o falante se comprometeria um pouco mais com a verdade de sua proposição, já que o fato foi

\footnotetext{
3 Veja-se o quadro 1 , na seção 4.

${ }^{4}$ Para exemplificação dos valores atribuídos ao PPC, utilizamos ocorrências oriundas do Corpus do Português de Davies e Ferreira (CdP).
} 
"visto, verificado com os seus próprios olhos", 5 como pode ser interpretado a partir dos seguintes enunciados:

(02) [...] Ah... na beira-mar acho que atualmente dá tudo, porque eu tenho visto casas à beira-mar com todas as coleções de plantas que você quiser imaginar - eu acho que é muita questão de adubo. (CdP, séc. XX)

(03) [...] Acho que hoje em dia por exemplo muitas crianças têm dor de cabeça enxaqueca fortíssima que não tinham antigamente $[. .$.$] - agora eu acho que a$ influência é marcante sobre criança apesar de eu não ter crianças, mas as que eu tenho visto sofrem influência marcante do vocabulário, maneira de falar e de se comportar. (CdP, séc. XIX)

De fato, são vários os contextos avaliativos em que o PPC esteve associado a ver e ouvir em nossa amostra, sendo que, a partir dos dados encontrados no $\mathrm{CdP}^{6}$, essa recorrência esteve presente já em séculos anteriores.

Em poucas palavras, então, consideramos que o PPC se especializou cada vez mais na constituição de contextos semântico-pragmáticos que caracterizam um evento como pluracional, seja através da ocorrência junto a expressões adverbiais, como muitas vezes, seja a partir da repetição inferida pragmaticamente (Cf. BECKER, 2016, 2020), ou ainda através da leitura durativa obtida por meio de predicados estativos. Nessa dinâmica, uma hipótese é a de que o PPC captou diversas funções discursivas em sua evolução, haja vista a repetição de eventos inferida em seu uso. Destacamos, portanto, o papel da interação comunicativa para a (re)organização de uma forma em cada subsistema, segundo discute Görski $(2020)^{7}$. Por exemplo, para Squartini e Bertinetto (2000), a emergência das formas compostas de pretérito perfeito teve como finalidade reintroduzir um paradigma perfeito nas línguas românicas, no sentido de expressar uma função semântica de destacar o resultado atual de um evento passado.

\footnotetext{
${ }^{5}$ De acordo com Squartini (2018, p. 9, tradução da autora), é a combinação de uma compreensão indireta do falante e de sua percepção direta que justifica o "sentido genuinamente 'evidencial' dos verbos de percepção, no qual o falante é também intelectualmente envolvido como fonte, e não como mero apreensor de uma fonte externa."

${ }^{6}$ Conforme será apontado na parte final do estudo, através do quadro 1, que expõe a distribuição do PPC segundo alguns verbos mais frequentes de cada classe acional. Becker (2016), Amaral e Howe (2012) e Duarte (2010) retratam um pouco da situação anterior em que o verbo "haver" era o auxiliar mais frequente na composição dessas perífrases, antes do verbo "ter".

${ }^{7}$ Basicamente, o fenômeno de gramaticalização pode ser compreendido da seguinte maneira: "um item ou construção frequentemente utilizados em contextos comunicativos particulares adquire função gramatical" (GORSKI, 2020, p. 4345). É possível ver uma descrição completa sobre (multi)funcionalidade em Görski et al. (2002).
} 
Por fim, trazemos algumas questões que permeiam a abordagem desse tema no presente estudo. A existência no sistema verbal do português de duas formas de pretérito ${ }^{8}$ seria um indicador de que, ao menos na diacronia, essas formas foram em algum nível da língua funcionalmente equivalentes? A presente situação sincrônica é uma consequência da evolução diacrônica das duas formas, sobretudo, do PPC, que se desviou de uma trajetória inicial em direção a uma função perfeita ${ }^{9}$ (de relevância atual) e talvez, posteriormente, aorística, como ocorreu com as perífrases análogas em outras línguas? Por fim, estaria o português em um estágio final de um provável cenário anterior de pouca competição, iniciado em fases anteriores da língua, quando o PPC também alcançava as leituras resultativa e universal ? $^{10}$ Os exemplos subsequentes, (04) e (05), ilustram o PPC nesses contextos em que se aproximava mais do PPS.

Em nosso estudo, entretanto, o intuito não é contemplar todas essas questões. Primeiramente, porque as formas simples e compostas de pretérito perfeito não estão sendo consideradas variantes. A análise, como se propõe, busca discorrer sobre a semântica do PPC, delineando seus valores no português contemporâneo, os quais convergem e divergem de outras leituras diacrônicas que nele se pode obter. Assim, aponta-se de que modo o PPC foi se distanciando de um trajeto inicial, como nos usos anteriores, em que aparecia inclusive com o advérbio já, - também encontrado em enunciados de Becker (2016), Carvalho et al. (2010) e Barbosa (2008, 2014). Esses casos, distantes na língua moderna ${ }^{11}$, configuram uma potencial situação linguística de sobreposição entre os usos do PPS e PPC. Vejam-se os exemplos:

(04) Já tenho comprometido a salvação de minha alma. (CdP, séc. XVIII)

(05) Já tenho viajado muito sozinho para estar perfeitamente escabreado dessa desgraça. (CdP, séc. XVIII)

\footnotetext{
${ }^{8}$ Essas duas formas de pretérito se distinguem do pretérito mais-que-perfeito, que denota um evento anterior a um ponto de referência anterior ao momento de fala.

9 Definição utilizada por Squartini e Bertinetto (2000) para distinguir a expressão aspectual de um tempo verbal sem fazer referência à nomenclatura utilizada especificamente para denominar dados tempos verbais ditos perfeitos.

${ }^{10}$ Veja-se Becker (2020) para uma descrição minuciosa de como o crescimento de leituras pluracionais coincide com o quase desaparecimento de leituras tradicionais de perfeito.

${ }^{11}$ Mais precisamente tratando-se do Português do Brasil, pois aparecem ainda com certa recorrência em dados do Português Europeu até o século XIX, segundo encontramos em nossa amostra oriunda do CdP, e até no século XX, também no PE, segundo Barbosa (2008).
} 
Em segundo lugar, de acordo com a Teoria de Variação e Mudança introduzida por Weinreich, Labov e Herzog (1968), seria preciso considerar variadas motivações e fatores de diferente natureza que intervêm no sistema linguístico. Ainda assim, ao longo das próximas seções, esses questionamentos acompanham a discussão proposta, que se volta essencialmente à caracterização do PPC no português moderno ${ }^{12}$, com maior foco em dados do século XX, utilizados para a exemplificação de leituras semânticas, assim como se debate a (multi)funcionalidade, no nível discursivo-pragmático, encontrada pelo pretérito composto nessa atual dinâmica linguística. ${ }^{13}$

Finalmente, passamos a apresentar a organização do estudo. Primeiramente, será realizada uma exposição sobre as leituras do PPC em competição na diacronia, em que se recuperam os estágios de gramaticalização de Harris (1982), também discutidos por Squartini e Bertinetto (2000), para situar a proposta de Becker $(2016,2020)$, em descrever várias leituras identificadas na história do $\mathrm{PPC}$, as quais teriam levado às principais leituras que caracterizam a semântica do PPC hoje. Em um segundo momento, a discussão se assenta mais propriamente na descrição do PPC em seus valores durativo ou iterativo, em que se toma como ponto de partida Ilari (2001) para essa caracterização. Segue-se, então, para a fundamentação teórica sobre o aspecto verbal e sobre as leituras do perfeito, norteadas por Kiparsky (2002), Klein (1992) e Comrie (1976). Depois, discute-se acerca de alguns contextos diacrônicos em que o PPC parecia se sobrepor ao PPS em algumas funções, como em determinados enunciados em que se identifica uma leitura universal, ou mesmo existencial e até resultativa. Em seguida, expõe-se um pouco dos resultados verificados através dessa análise qualitativa, em que se priorizou investigar outras funções para o PPC a partir da presença dos principais verbos associados ao seu uso, distribuídos segundo categorias relacionadas ao aspecto. Por último, apresenta-se a contribuição final deste estudo.

No que tange à amostra, para exemplificação dos valores atribuídos ao PPC, utilizamos ocorrências oriundas do Corpus do Português de Davies e Ferreira (CdP) em razão da ampla amostragem diacrônica, que inclui registros que datam do século XIIV até o século XX, possibilitando-nos olhar para alguns verbos que mais aparecem na forma do PPC, diferenciados por classes acinais, o que é relevante à subsequente análise e discus-

\footnotetext{
12 Com os termos português moderno ou contemporâneo estamos fazendo referência à fase da língua que compreende os séculos XIX, XX e XXI, segundo Brocardo (2012).

13 É possível ver uma descrição completa sobre (multi)funcionalidade em Görski et al. (2002).
} 
são de suas possíveis funções e leituras semânticas. ${ }^{14}$

Cabe, por último, ressaltar que, embora este estudo não faça parte dos vários trabalhos sobre as formas verbais em variação no português da Região Sul do Brasil, organizados ou orientados pela $\operatorname{Prof}^{a} \operatorname{Dr}^{a}$ Edair Görski a partir do seu grupo de pesquisa Tempos Verbais e Verbos Modais, ele se assemelha, em certa medida, à proposta, que incluía não somente investigações de formas verbais variantes, mas também análises de seus valores e funções dentro do sistema verbal do português. ${ }^{15}$

\section{A expressão do PPC a partir de leituras em competição na diacronia}

O verbo em português compõe um dos sistemas que mais preserva algumas particularidades do seu ponto de origem, no que se refere às formas desenvolvidas a partir do tema do perfeito. Um exemplo relevante desse traço mais conservador seria a presença, ainda recorrente, de uma forma remanescente do subjuntivo perfeito e do futurum exactum latino, o futuro do subjuntivo, como discutido em Bittencourt (2014) e em outros estudos $^{16}$. Além do mais, destacamos a conservação de um pretérito perfeito simples, em uso frequente, possivelmente como um reflexo direto do perfeito sintético latino, o que pode ser considerado como um dos fatores que restringem a expansão do PPC em outros domínios. ${ }^{17}$ Nesse ponto, o português diferencia-se assim das principais línguas românicas, que limitaram os contextos de uso das formas simples, ao passo que expandiram o

${ }^{14}$ Observamos que os casos que são do Português Europeu serão acrescidos de PE, de modo que o restante está subentendido como do Português Brasileiro (PB). Em virtude de não ser realizada nenhuma avaliação quanto às duas variedades, citamos o estudo de Barbosa (2008), que retrata alguns aspectos da variação entre $\mathrm{PE}$ e $\mathrm{PB}$, mas não significativos, em termos de interpretação da semântica do PPC contemporâneo.

${ }^{15}$ Em síntese, o conjunto desses estudos pode apresentar um vasto retrato da situação linguística atual, de competição ou não, de várias formas verbais no PB. Como são muitos trabalhos, citamos neste momento alguns do que tratam especificamente da análise dos tempos verbais que têm como base o tema do perfeito, como Bittencourt (2014), acerca do futuro do subjuntivo; Back (2012), sobre o pretérito imperfeito do subjuntivo, e Coan $(1999,2003)$, que trata do pretérito mais-que-perfeito. Além da categoria verbal, outras análises tratam de fenômenos da língua em uso, como o dos marcadores discursivos: Valle (2014) e Tavares (2002).

${ }^{16} \mathrm{Na}$ sincronia das línguas românicas, essa seria a única forma a refletir as suas antecessoras em orações temporais, afirma Becker (2011). Sobre a recorrência do futuro do subjuntivo em português, os estudos variacionistas de Macedo (1980) e Gryner (1992) detalham a situação sincrônica.

${ }^{17}$ Em um estudo subsequente, não publicado, analisamos as formas simples de pretérito como um reflexo direto do subsistema perfeito latino, em vários aspectos e funções. Citamos ainda a discussão de Bártoli (1946) e dos subsequentes estudos filológicos de Bueno (1958) e Neto (1977) sobre a formação do português. Sobre o perfeito sintético, de modo sucinto, era formado por duas fontes antecessoras principais: uma originária no aorístico (-s; -i) e outra num antigo perfeito, as quais foram ainda amalgamadas a uma inovação que atingiu sobremaneira os verbos da primeira e quarta conjugação, em que o perfeito passou a ser expresso pelo acréscimo de (-v), como em amo (pres.), ama-v-i (perf.) Como resultado, o perfeito ativo alcançava mais de um valor aspectual (Cf. PINKSTER, 1987; EMBICK, 1998). Já sobre a expressão ampla e variada do aspecto pelo PPS em português, veja-se Travaglia (1994). 
emprego das formas compostas de pretérito (equivalentes os PPC) em funções perfeitas (de relevância corrente) e perfectivas, como o italiano. Vejamos um exemplo:

(06) Latim. Vidi enim et cognovi quid maxime spectares... (T. Cic. Ligarius 11)

'Porque vi e soube o que você mais considera/preza'

Italiano. Ho visto e conosciuto ciò che tu più ammiri.

Precisamente no que tange à emergência das formas compostas com função perfeita nas línguas, Harris (1982) busca explicar a evolução dessas perífrases através de um processo de gramaticalização desenvolvido em quatro etapas. Inicialmente, as construções compostas surgem com um valor resultativo (estágio I) - estado existente e atual como resultado de um evento anterior (em que leituras de perfeito começam ser possíveis), até finalmente alcançarem um estado aorístico, perfectivo denominado de estágio IV. Nessa última fase, as formas compostas podem se sobrepor às formas simples, como teria ocorrido em francês e em italiano padrão, por exemplo. No estágio II, em que o PPC do português pode ser situado, as formas compostas deixam de assinalar somente um estado resultativo e se associam à noção de persistência e iteração de um evento. Já a fase III pode ser identificada nos casos em que as formas compostas expressam um evento anterior que possui alguma relevância ${ }^{18}$ atual, como é o caso das construções perfeitas em muitas variedades do espanhol.

Em síntese, os estágios diacrônicos de gramaticalização propostos por Harris (1982), que explicam a presente polissemia funcional identificada nas línguas, serão aqui ilustrados, porém, com uma exemplificação diferente - com intuito de adiantar a subsequente exposição ancorada em Becker (2016) - a partir de registros em português (arcaico e moderno), espanhol, e italiano:

(i) I: resultativo - "Perdoado te tem Deos os teus pecados." (Port. arcaico, CdP, séc. XIV)";

(i) Estágio II: perfeito de persistência: "Tenho trabalhado muito na arquitetura." (Port. contemporâneo, CdP, séc. XX);

(i) III: perfeito de relevância atual: "Al mismo tiempo se queja de su esposa que no

\footnotetext{
${ }^{18}$ Klein (1992) conceitua e problematiza essa noção de relevância aplicada, já que estaria situada num âmbito mais pragmático de sentido, como no caso do Present Perfect em inglês. Squartini e Bertinetto (2000) retomam esse debate.
} 
ha studiado una carreira universitária." (Esp., CORPES XXI-Equador, RAE);

(i) Estágio IV: função aorística: "Leri, ho discusso con i rappresentanti delle compagnie aeree $[\ldots]$ (It.) $)^{19}$

Por outro lado, Squartini e Bertinetto (2000, p. 17) afirmam que cabe ponderar alguns pontos desenvolvidos na proposta de Harris, por exemplo, a maneira como as línguas como italiano e francês passaram pelo estágio II, em função da escassez de dados mais antigos; além disso, consideram problemática a concepção do estágio II como uma fase intermediária, como no caso do PPC em português.

\begin{abstract}
Embora o desenvolvimento sugerido por Harris seja plausível, uma interpretação alternativa é igualmente possível. De acordo com ela, o estágio II, correspondente ao sentido inclusivo do CP, não seria o segundo passo de movimento com direção aorística, porém mais que isso, um desenvolvimento totalmente independente no qual valores acionais, ou melhor, uma interação peculiar entre valores acionais e aspectuais estão (atuando) em um primeiro plano. (SQUARTINI; BERTINETTO, 2000, p. 17 , tradução da autora $)^{20}$
\end{abstract}

Logo, consideramos que os estágios propostos em Harris funcionam como um sólido ponto de partida para compreender a polissemia do perfeito na sincronia; porém, parece necessário situar a presente discussão além desse enquadramento, particularizando um pouco mais a história de evolução do PPC em português. Para tanto, descrevemos uma análise também diacrônica da forma, com base em Becker (2016), assim como discutimos vários pontos desenvolvidos por Ilari (2001) e Laca et al. (2010) posteriormente, em que os autores colocam em primeiro plano a semântica do aspecto verbal e das classes acionais do verbo na caracterização especial do PPC, a partir da configuração de cada predicado verbal. Adicionalmente, cabe citar o estudo de Amaral e Howe (2012), que também retratam a expressão e gramaticalização do PPC no português arcaico e incluem outros fatores morfossintáticos, além dos semânticos, no processo de mudança

19 (iii) 'Ao mesmo tempo reclama da sua esposa que não fez uma carreira universitária'; (iv) Leri, ho discusso con $i$ rappresentanti delle compagnie aeree hanno dichiarato di non essere ancora pronti per fare una stima delle proprie perdite." (It., europarl.europa.eu) 'Ontem, conversei com representantes de companhias aéreas e eles disseram que ainda não estão prontos para avaliar suas perdas.'

${ }^{20}$ Although the development suggested by Harris is plausible, an alternative interpretation is equally possible. According to this, stage II, corresponding to the inclusive meaning of the $\mathrm{CP}$, would not be the second step of the aoristic drift, but rather a totally independent development in which actional values, or rather a peculiar interaction of actional and aspectual values, are foregrounded. (SQUARTINI; BERTINETTO, 2000, p. 17) 
linguística através de várias etapas de reanálise, que promoveram interpretações resultativas às construções formados por tenho + particípio, de modo similar à situação anterior (herdada) com habeo + particípio.

Becker $(2016,2020)$ apresenta uma particular trajetória na expressão histórica do PPC em português, através da análise minuciosa de registros históricos (compostos por uma amostra de cartas históricas do PB e ocorrências do Corpus Informatizado do Português Medieval e do Corpus do Português) situados entre os séculos XV e XXI. Em seus estudos, as etapas da mudança linguística do PPC estão ancoradas numa análise semântica da forma, bem como no papel de cada classe de verbos nesse processo de evolução, considerando-se assim, por exemplo, a relação entre os verbos accomplishments e achievements no processo inicial de estabelecimento da leitura resultativa, além das especificidades dos verbos como de percepção, cognição, comunicação etc. Primeiramente, o autor situa a forma em sua expressão contemporânea como caracterizada pela expressão pluracional e, então, delineia várias etapas em que o PPC foi obtendo diferentes leituras semânticas, assim como se alternando entre elas. Essas leituras, apesar de inicialmente terem sido projetadas como uma extensão da leitura resultativa, acabaram por direcionar a evolução do PPC a leituras de pluralidade. Para o autor, "a evolução semântica do PPC é um caso da mudança de uma categoria linguística lenta e gradual que se produz entre o século XV e o século XX. Trata-se de um caso exemplar que ilustra as diferentes etapas [...] de um processo de mudança complexo." (BECKER, 2016, p. 39)

Em síntese, o autor propõe que o PPC passou por várias fases em sua evolução diacrônica, quando diferentes leituras foram possíveis de serem obtidas a partir da leitura resultativa inicial, as quais promoveram o desenvolvimento das duas principais leituras contemporâneas: a iterativa e a durativa, de que trataremos na próxima seção. Em sua proposta, Becker $(2016,2020)$ afirma que, inicialmente, quando começou sua função gramatical no português, por volta do século XV, o PPC estava associado à leitura resultativa e podia atuar como um típico perfeito resultativo, expressando um estado resultante de um evento anterior. Para tanto, essa leitura é ilustrada numa ocorrência do século XV, em que a expressão fazer juramento "descreve um ato no passado cujo estado resultante possui vigência no presente e para além dele” (BECKER, 2020, p. 152):

(07) "E vós tendes todos mim terra e sodes meus vassalos que me havedes feito menageme juramento por este vos rogo, que voz me ajudedes [...] (Corpus Informatizado do Português Medieval: Demanda). 
Nesse estágio ainda, o PPC teria desenvolvido uma extensão da leitura resultativa, dita sumativa, que corresponderia à interpretação inicial de pluralidade vinculada ao PPC, isto é, de uma soma de eventos, instâncias de um mesmo tipo. Segundo Becker (2020, p. 167): "a leitura sumativa decorre seja de um sintagma nominal objeto direto no plural (X tem feito roubos), seja de uma expressão adverbial que contém um determinante indefinido com valor distributivo (p. ex., em cada N)."21

(08) E em cada mosteiro destes tem posto no altar, em logar de fotoque, a figura de Caysan [...] (Frois: Japam2, séc. XVII) ${ }^{22}$

Outrossim, a diferenciação do autor entre leitura sumativa e iterativa é interessante, pois, enquanto a primeira precisa ser inferida pragmaticamente a partir de elementos da sentença no plural (sujeito ou complemento verbal), a segunda se projeta facilmente através da semântica de advérbios de frequência e quantidade. Logo, o valor, o alcance de uma leitura iterativa é maior sob a sentença do que uma leitura que decorre de uma inferência, como a sumativa. Dito de outra modo: "na leitura iterativa o quantificador tem escopo sobre a proposição inteira, enquanto a leitura sumativa provém de um constituinte encaixado [...]” (BECKER, 2020, p. 167), como se pode observar no exemplo a seguir: "Muito se tem falado sobre a denuncia vazia." (leitura iterativa)

Como desdobramento da leitura sumativa, Becker especifica ainda uma leitura denominada 'incrementativa', também descrita em Laca (2010, p. 76) como incremental, em que se realça uma acumulação progressiva de resultados que projeta um ponto culminante através do uso do PPC, como em:

(09) Olhai o estado a que a gente de Ximabara tem chegado, por huma parte tenho ira, e por outra compaixão [...] (Frois: Japam1, séc. XVII) ${ }^{23}$.

Além dessas, o autor ainda discorre sobre leituras mais recentes, como a iterativa e a durativa - tratadas mais adiante -, que se expandiram cada vez mais a partir dos séculos XVIII e XIX, o que está em consonância com a análise de Barbosa (2008), e retrata ainda

\footnotetext{
${ }^{21}$ Ademais, em situações bem específicas, a leitura sumativa pode aparecer com verbos de estado, como em "[...] nos púlpitos têm havido quem falasse." (Pe. Vieira), conforme o autor (op. cit.).

22 Esse exemplo foi extraído de Becker (2020, p. 153).

${ }^{23}$ Essa ocorrência foi extraída de Becker (2016, p. 31).
} 
uma interessante leitura na qual o PPC atuava como um marcador de relevância atual ${ }^{24}$, a partir da associação com verbos performativos e de comunicação, como nos exemplos a seguir.

(10) Estimarei que esta execução que tenho dado Real ordem (Carta/Pe/1711)

Vossa majestade tem ordenado a Vossa Excelência tudo o que quer que se faça nessa Capitania com muita Recomendação (Carta/RJ/1773)

Com base nessa discussão, uma descrição que sintetiza as etapas da evolução do PPC poderia ser assim apresentada:

1. Em algum momento, a partir dos séculos XV ou talvez XIV, o PPC se apresenta na língua com uma leitura resultativa.

2. Já no século XV, o PPC começa a ser usado em uma leitura de pluralidade, a sumativa, obtida através de inferências pragmáticas, a partir da presença de algum sintagma nominal no plural.

3. No século XVI, já é possível identificar várias ocorrências do PPC com quantificadores adverbiais, como muito, várias vezes etc., mas a leitura resultativa ainda é frequente.

4. A leitura iterativa já é alcançada no século XVII, muito em razão da recorrência do PPC com esses quantificadores, embora a resultativa ainda se apresente, apesar de que com uma frequência menor.

5. A leitura durativa é identifica no século XVIII e já demonstra uma dinâmica de crescimento, ao passo que a resultativa já pode ser considerada marginal.

6. Nos séculos XIX e XX, as leituras iterativa e durativa predominam nos dados, e sobretudo a durativa continua a se expandir. A partir desse momento, o PPC já recebe uma interpretação pluracional, independentemente da presença de expressões adverbias ou de inferências. De fato, Ilari (2001) também afirma que, no português moderno, o PPC recebe uma leitura iterativa, estando os quantificadores presentes ou não na sentença.

Para complementar, cabe observar que a natureza histórica dos dados pode não representar precisamente a realidade da situação linguística de outras fases da língua. Ainda assim, podemos considerar que esse processo de mudança linguística não se iniciou antes do século XV, quando ainda é possível encontrar ocorrências de tem + particípio em que a construção não foi (re)interpretada como uma única unidade sintático-semântica e por conseguinte, posteriormente como perífrase verbal ${ }^{25}$. Veja-se um exemplo:

\footnotetext{
${ }^{24}$ Nesses usos, Becker argumenta que o PPC imprime um valor vinculante ao ato legal ou à vigência da informação veiculada. Desse modo, "mesmo se o ato de realização se situa no passado, o seu resultado ou efeito se verifica como atual, relevante e vinculante" (BECKER, 2020, p. 174).

${ }^{25}$ Paralelamente, é possível considerar ainda que essas perífrases com "ter" ainda não substituíram completamente as construções com haver + particípio nos séculos XV e XVI, as quais em alguma medida foram herdadas do latim tardio (habeo + particípio acusativo).
} 
(11) E algumas cousas tenho scriptas no livro que faço de saber bem andar a cavalo e fazer as boas manhãs que se costumam fazer em eles. (Leal Conselheiro, séc. $15, \mathrm{CdP}$ )

Desse modo, segundo a perspectiva de $\operatorname{Becker}(2016,2020)$, ao passo que o PPC foi se especializando e adquirindo novos valores que gradativamente foram imprimindo um valor iterativo à forma, conforme discutiremos melhor ao longo do estudo, muitas leituras tradicionais que caracterizam o perfeito, mais frequentemente a resultativa - que, através de Kiparsky (2002), pode se configurar como perfeita ${ }^{26}$-, foram sendo perdidas em sua expressão ao longo dos séculos.

\section{A semântica do aspecto verbal e a leitura durativa ou iterativa do PPC}

Em português, a perífrase formada pelo verbo auxiliar ter, no presente do indicativo, seguido de particípio verbal, segundo a gramática descritiva de Perini, basicamente, expressa: "um evento e que começou no passado e continua sem interrupção até o presente" (PERINI, 2016, p. 333), como no exemplo a seguir.

(12) [...] um time entrosado, cuja base tem trabalhado junta há anos. (CdP, séc. XX)

Perini (2016) afirma ainda que "uma consequência da semântica dessa construção é que ela é incompatível com qualquer indicação de que o evento relatado já se completou." (PERINI, 2016, p. 334) Dito de outro modo, em português os eventos concluídos antes do momento de fala não são expressos pelo PPC contemporâneo, mas preferencialmente pelo PPS.

De fato, na sincronia do verbo, as diferenças aspectuais entre os pretéritos simples e composto parecem restringir uma competição real entre as formas, embora haja estudos que ilustrem alguns contextos muito específicos de sobreposição entre os pretéritos, como em Barbosa $(2008,2014)$ ou ainda em Carvalho et al. (2010), que discutem a semântica do PPC também através dados do Português Europeu. Em suma, tradicionalmente, o PPS é dito como a forma de passado preferida para codificar o aspecto perfectivo em por-

\footnotetext{
${ }^{26}$ Sobre esse ponto, isto é, qual leitura - resultativa ou a dita perfeito de relevância (normalmente presente em estágio posterior de gramaticalização) - representa de fato o aspecto perfeito, veja-se a discussão em Lindsted (2000). Neste estudo, assume-se que a resultativa já pode ser considerada uma leitura típica do perfeito.
} 
tuguês, ao passo que a caracterização do PPC aqui utilizada e ancorada na literatura de enfoque mais semântico - como em Becker (2016), Carvalho et al. (2010), Laca (2010) e Ilari (2001) - vincula-o à pluralidade ou continuidade de um evento. Assim, aventamos a hipótese de que os poucos contextos que poderiam conduzir uma potencial situação de variação estariam na diacronia, quando o PPC não era associado apenas à iteração, mas a outras leituras também..

Isso posto, ilustramos mais alguns dados em que é possível contemplar o valor iterativo do PPC, em (13), bem como o durativo, em (14), e ainda uma ocorrência com o PPS, (8), em que se observa a singularidade do evento descrito.

(13) Não tenho lido, não tenho estudado, não escrevi (a carta) à Vossa Excelência, mas tenho servido a uma senhora $[\ldots ..](\mathrm{CdP}, \mathrm{PE} \text {, séc. XIX })^{27}$

(14) Olhe, tia, aposto eu que o tio Ambrósio em toda a sua vida só tem amado a tia. (CdP, séc. XIX)

Esses enunciados ilustram a expressão do PPC, tanto através da comparação direta com o PPS, em (13), onde se interpreta claramente que "escrevi" seria um evento único e que deveria estar concluído antes do momento de fala, diferentemente da leitura de pluralidade assumida pelos eventos no PPC, ou quando um predicado estativo interfere, e o PPC assume um valor durativo (em 14). Assim, apontamos como as propriedades aspectuais do predicado e o conteúdo lexical do verbo constituem fatores que interferem na expressão do PPC.

Por fim, concernente à expressão temporal, consideramos que o PPC indica que o evento está situado em um intervalo de tempo que se inicia no passado e segue até o momento de fala, podendo ainda ser interpretado como transcorrendo no momento da declaração ou como um evento que poderá persistir após a enunciação, em razão da implicatura de que, uma vez que o evento se repetiu no passado, poderá durar ou persistir até o futuro, conforme uma intepretação possível do enunciado (15).

(15) Sexta-Feira era um papel bem pequeno no início da novela e ultimamente tem crescido. (CdP, séc. XX)

\footnotetext{
${ }^{27}$ É importante observar que um verbo não accomplishment com o traço +dinâmico pode vir também a alcançar uma representação télica, de acordo com o predicado verbal, já que eventos e situações não são caracterizados só pelo verbo, mas também por seus argumentos. Por exemplo, de acordo com Comrie (1976), "Ele está cantando descreve uma situação atélica, ao passo que Ele está cantando uma canção denota uma situação télica” (p. 44).
} 


\subsection{A aspecto perfeito e as leituras de pluralidade do PPC}

A semântica do aspecto verbal busca analisar a contribuição dessa categoria na interpretação das propriedades do evento, seja no âmbito do conteúdo lexical do item verbal ou através da morfologia atribuída às categorias gramaticais que codificam o tempo e o aspecto nas línguas. No caso das formas que assinalam o perfeito, há uma série de fatores que precisam estar alinhados à expressão de um evento passado que seja persistente, relevante no momento presente, ou ao menos que o estado resultante seja posto em destaque no momento da enunciação.

No geral, a semântica do perfeito, bem como a do PPC, em particular, apresenta uma forte sensibilidade ao Aktionsart do verbo. Assim, em cada predicado verbal, as propriedades aspectuais constituem um fator determinante na projeção das leituras de pluralidade ou durativa do PPC. Basicamente, em predicados estativos, o PPC obtém uma leitura durativa, como em (16), enquanto, em predicados não estativos, (17) e (18), sobretudo a partir de verbos télicos, ele pode adquirir uma leitura iterativa. Podemos identificar que a expressão pluracional típica do PPC pode remeter a interpretações frequentativas e habituais, conforme discorrem, sobremaneira, Laca (2010) e Carvalho et al. (2010, p. 68), dentre os estudos já citados.

(16) Tenho estado muito isolada de todos. (CdP, séc. XX)

(17) Essa é uma pergunta que se tem feito muitas vezes. (CdP, séc. XX)

(18) Tenho estudado, tenho lido, tenho feito observações a ver se encontro outro tipo igual (CdP, séc. XX)

Um dos pontos mais cruciais para a caracterização do PPC aparece em Ilari (2001), haja vista que o autor apresenta e discute o embate, bem antigo, entre "Paiva Boléo e Viana” sobre a interpretação semântica atribuída ao PPC, como durativa ou de repetição. Para o autor, há alguns problemas em delimitar um tratamento unificado à semântica do PPC, realçando ou seu valor durativo ou iterativo apenas. Na primeira opção, seria necessário formular que o PPC essencialmente "faz referência a um período, e nele, alguma coisa dura." (ILARI, 2001, p. 146), o que se verificaria facilmente nos predicados estativos ou de atividade, visto que em todos os momentos do intervalo a afirmação dita precisa ser verdadeira" (ILARI, 2001).

Dito de outro modo, a partir de Taylor (1977), se um estado for verdadeiro em um dado intervalo, então ele será verdadeiro em todo subintervalo, que inclui cada momento. 
Isso poderia ser verificado no exemplo (16), estativo, mas seria difícil em um predicado télico. Ilari (2001) propõe, então, que "uma manobra para incorporar esses casos consiste em admitir que tanto a repetição quanto a duração são manifestações de algum processo mais genérico e abstrato, a ser melhor caracterizado, que dura no período em questão.” (ILARI, 2001, p. 147).

Já na segunda opção, em que se atrela o PPC à repetição, em resumo, ele seria definido como uma forma verbal que denota uma pluralidade de eventos do mesmo tipo, ocorridos sucessivamente em um intervalo temporal iniciado antes do momento de fala, o que acarretaria problemas no que concerne a sentenças com sentido existencial. Por fim, o autor considera que melhor seria assumir que as características do predicado afetam diretamente a interpretação durativa ou iterativa do PPC do que uma semântica unificada.

Em síntese, a caracterização dessas leituras é importante sob diversos aspectos, dentre os quais destacaremos os dois mais significativos, uma vez que se complementam no estudo da evolução e mudança das formas em cada subsistema da língua. Primeiro, para a investigação de momentos em que duas formas podem expressar valores equivalentes, como por razão de um processo de emergência de uma nova forma ou construção. Logo, em algum momento da língua, formas equivalentes semanticamente passam a coocorrer e competir (ou não). ${ }^{28}$ Em segundo lugar, essas diferenciações podem revelar, ou ao menos sugerir, alguns fatores que podem estar atuando para restringir - ou bloquear certas leituras, na perspectiva mais estrutural de Kiparsky $(1989,2005)$ - uma forma de pouca produtividade no sistema linguístico no alcance de uma dada leitura semântica.

\subsection{As leituras tradicionais do perfeito, a estrutura da leitura resultativa}

Nesta subseção, apresentamos uma fundamentação teórica acerca da categoria perfeito e suas leituras tradicionais com base em Comrie (1976), Klein (1992) e, sobretudo, Kiparsky (2002), que distingue a estrutura do evento em dois tipos básicos: simples, a partir de predicados estativos e de atividade, e complexos, no caso dos predicados télicos. Dessa forma, a configuração temporal do perfeito é delineada a partir da estrutura de cada predicado verbal. Em momento posterior, correlacionaremos algumas dessas leituras a antigos usos do PPC.

Em resumo, nessa exposição, aproximamos definições e nomenclaturas situadas em Kiparsky (2002), Comrie (1976) e Klein (1992) que, embora se assentem essencial-

\footnotetext{
${ }^{28}$ Dito de outro modo, para "identificar formas coocorrentes para uma mesma função no interior de um
} dado domínio (foco dos estudos variacionistas)" (GORSKI, 2020, p. 4345). 
mente na expressão do (tempo)aspecto perfeito em inglês (present perfect), discutem o perfeito como uma categoria universal, além de que são tradicionalmente tomadas como base para a análise dessa categoria em outras línguas, como em Lindstedt (2000) e Laca (2010), dentre outros trabalhos. Algumas das leituras tradicionais do perfeito serão descritas através da correspondência entre a estrutura do evento e de dadas configurações temporais, as quais são: (i) existencial, (ii) universal e (iii) resultativa - visto que não encontramos registros de PPC com outras leituras, como de passado recente ("hot news"), por exemplo.

Inicialmente, então, definimos a seguinte nomenclatura como parâmetro: (i) E: refere-se ao tempo do evento, isto é, ao intervalo de tempo durante o qual o evento ocorre ou se desenvolve; (ii) S ou MF: o momento de fala, da enunciação; (iii) R: tempo de referência temporal, que pode ser indicado por advérbios de tempo, por exemplo. Logo, uma configuração como (a) implica que o evento e a referência temporal do advérbio são anteriores ao momento de fala.

Figura A: Representação para o pretérito simples
a. E, $\mathrm{R}$
$\mathrm{S}(\mathrm{MF})$

\subsubsection{As leituras existencial, universal e resultativa}

A leitura existencial, também denominada experimental, é obtida quando um ou mais eventos de um determinado tipo ocorreram durante um intervalo de tempo passado, com base em Comrie (1976). Basicamente, na leitura existencial, identifica-se que o evento denotado por um predicado verbal atélico ou télico iterativo está contido no intervalo temporal anterior ao momento da declaração e permite ainda a pressuposição de que a recorrência desse tipo de evento possa continuar, bem como a implicatura de que ele não está se passando durante a enunciação, de acordo com Kiparsky (2002, p. 4-5).

Já a leitura universal é obtida quando o intervalo temporal de um evento (ou instância do evento) télico iterativo ou atélico se estende por todo o período anterior, até terminar e incluir-se no momento de fala, isto é, tendo esses pontos como fronteiras inclusivas, descreve Kiparsky (2002). Normalmente, requerem advérbios indicando uma duração, um intervalor de tempo, mas não um ponto temporal específico, descreve Klein (1992).

Em síntese, "para uma sentença com um perfeito ser verdadeira em uma leitura universal, o estado ou processo deve se estender por toda duração do período terminando sob R”, segundo Kiparsky (2002, p. 5, tradução da autora). 
Assim, a diferença entre as duas leituras situa-se nos limites do traço temporal denotado pelo predicado verbal. Basicamente, na leitura existencial, um evento ou subeventos (de um mesmo tipo) ocorrem em um intervalo de tempo E, sem estender-se, necessariamente, por todo esse intervalo, enquanto na leitura universal, o evento é coexistente com E em todo seu intervalo temporal.

Por último, no caso da leitura resultativa, "o estado presente é referido como sendo o resultado de alguma situação passada." (COMRIE, 1976, p. 56, tradução da autora).

Os predicados caracterizados como de natureza acomplischment e achievement são os maiores representantes de uma típica leitura resultativa, uma vez que o seu conteúdo lexical envolve uma mudança de estado, que nasce de uma transição que está temporariamente localizada entre E e R, segundo Kiparsky (2002). No primeiro caso, é necessária uma atividade que conduza a uma mudança de estado (ex.: construir, quebrar); enquanto no segundo, o evento em si consiste em uma mudança de estado (ex.: morrer, realizar), a partir de Vendler (1967). ${ }^{29}$

Desse modo, podemos dizer que um verbo télico descreve uma situação que inclui um ponto no qual necessariamente o evento chegará ao fim, isto é, quando então o evento descrito deverá estar concluído, tendo um ponto final. Em "Ele está construindo uma casa”, por exemplo, chegará um momento em que o sujeito completará ação de construir, ou seja, a situação descrita deverá chegar ao fim, diferentemente de "Ela está cantando" (uma situação atélica).

No caso dos "predicados accomplishment, a mudança de estado é temporariamente localizada no onset do $\mathrm{R}$ tense e, dessa forma, a atividade que conduz a isso deve imediatamente preceder R” (KIPARSKY, 2002, p. 6, tradução da autora). A diferença em relação à presença de verbos classificados como achievement é que, nesse último caso, nenhuma atividade tem como implicatura ter sido localizada sob E.

\section{A expressão histórica do PPC em outras leituras: uma potencial aproximação com o PPS}

Neste momento, abordamos os usos do PPC na diacronia, com o propósito de discorrer sobre uma situação linguística diferente em que o PPC parecia estar entrando a partir do século XVI, por se tratar de um domínio típico do PPS também na língua arcaica,

\footnotetext{
${ }^{29}$ Na terminologia de Vendler (1967), além dessas duas classes, há ainda os predicados verbais que descrevem situações que ocorrem em algum momento entre um intervalo de tempo (entre t1 e t2), definidos como de estado, assim como os verbos de atividade, os quais denotam situações enquadradas em um intervalo $t$.
} 
de acordo com os trabalhos de Barbosa (2008, 2014) e Becker (2016). Para Barbosa (2008), a “distinção aspectual entre PPS e PPC encontrada (e perceptível) no português atual se consolidou apenas no século XX, pois, no período entre os séculos XVI ao XIX, podemos encontrar o PPC com valor semelhante ao de outras línguas românicas” (2008, p. 245). Contudo, a autora observa que já nesse período é possível encontrar vários dados em que se identifica a atual característica quantificacional do PPC de expressar uma pluralidade de eventos.

De fato, identificamos várias ocorrências em que é possível caracterizar algumas das leituras tradicionais de perfeito, embora numa frequência baixa, o que indicaria um uso marginal da forma. Esses casos podem ilustrar a passagem diacrônica de uma leitura inicial, tipicamente resultativa, na expressão de um evento em sua singularidade ou pluralidade a outras leituras características de uma outra categoria ou forma, como o PPS. Entretanto, a partir do século XIX, esses usos ficaram cada vez mais escassos, sobremaneira em ocorrências do Português do Brasil, afirmam os autores mencionados. Outrossim, Barbosa (2008, p. 246) observa que, a partir do século XVII, a percentagem de dados do PPC com valor exclusivamente perfectivo diminui e corresponde a aproximadamente $5 \%$ dos casos no século XIX, de acordo com sua amostra.

Isso posto, inicialmente, apresentamos um interessante exemplo em que o PPC parece atuar para marcar a relevância de um evento passado e perfectivo. No português contemporâneo, o PPS possivelmente seria a forma verbal escolhida para expressar essa função, bem como o favorito nos enunciados subsequentes.

(19) E tenho comprado uma fragata, a melhor destas províncias, nova, veleira, com vinte e oito peças de boa artilharia. (CdP, Cartas-Pe Vieira, séc. XVII)

Como podemos observar a partir dessa ocorrência, na diacronia, o PPC poderia ser utilizado para inscrever um evento em um intervalo de tempo que não inclui o momento de fala, diferentemente da sua expressão aspectual hoje, também em consonância com os resultados de Becker (2016) e Barbosa (2008). No português moderno, a partir dos séculos XIX e XX, uma diferença aspectual nítida entre as duas formas de pretérito no português atual é a de que o PPS situa um evento num intervalo temporal anterior, isto é, que exclui o momento de fala, ao passo que o PPC inscreve subeventos em um intervalo de referência que inclui o momento da declaração.

Vamos expor, então, alguns exemplos dos séculos XIX e XVIII primeiramente, em 
que se identificam outras leituras, além da resultativa, na expressão do PPC. Em seguida, apresentamos alguns dados dos séculos XVII, XVI e XV, em que a leitura resultativa se estabelece. O exemplo (vii), em particular, em que há a presença de "ainda”, mostra-se muito interessante, pois, segundo Lindsted (2000), numa perspectiva funcionalista, a sua ocorrência (como em inglês still) junto à forma seria uma marca indicativa de sua caracterização ainda como de um perfeito resultativo, em termos de estar pouco gramaticalizado, a ponto de receber uma interpretação de relevância atual. Contudo, neste estudo, não nos atemos a discutir a diferença entre os dois, uma vez que o PPC, conforme situado no estágio II de Harris (1982), não atingiu o estágio III (perfeito de relevância). ${ }^{30}$ Por último, ilustramos as ocorrências em que uma leitura resultativa pôde ser identificada.

Desde já, contudo, cabe observar que a interpretação dos enunciados e leituras em ocorrências situadas em estágios anteriores da língua pode divergir da leitura realizada por um falante da língua contemporânea. Ademais, a localização geográfica do falante também pode interferir numa dada interpretação.

(i) [Século XIX] Eu já tenho dito para o meu filho e para muita gente e, às vezes, rapazes: "Olhai rapazes, olhai que nós estamos na fim do mundo (CdP, PE).

(ii) [Século XIX] Já tenho falado para pessoas de todos o mundo, que vêm aqui. (CdP, PE).

(iii) [Século XIX] Quer dizer que depois da minha enfermidade nos Caetanos ele me tem visitado três vezes, todas elas repetidamente solicitado por mim. (CdP, PE)

(iv) [Século XVIII] Já tenho comprometido a salvação de minha alma (CdP).

(v) [Século XVIII] Já tenho viajado muito sozinho, para estar perfeitamente escabreado dessa desgraça (CdP, séc. XVIII).).

(vi) [Século XVIII] Só descendo em corda de laçar, e uma não chega nem duas, porque eu já tenho jogado pedra que leva batendo um tempão. (CdP).

Nos próximos enunciados, podemos considerar a presença da leitura resultativa associada ao PPC, uma vez que o estado consequente de um evento é posto em destaque na situação corrente.

(vii) [Séc. XVII] Aqui me não tem valido muito a autoridade da pessoa que V. S.a representa, porque fazendo oito semanas hoje que S. A. deu o meu livro ao inquisidor-geral, podendo-se rever em dois dias, ainda não tem saído daquele consistório. (CdP, séc. XVII)

\footnotetext{
${ }^{30}$ Ainda conforme discute Klein (1992), a leitura de um evento como de relevância atual acaba vinculada mais à esfera pragmática e menos à estrutura do evento, bem como à própria semântica da forma. Todavia, do ponto de vista tipológico, em que se busca investigar as origens das formas gramaticais de perfeito nas línguas - como em Bybee e Dahl (1989) e Bybee et al. (1994) -, essa distinção, além de outras acerca da categoria do perfeito, como no caso do perfeito evidencial, mostra-se mais necessária.
} 
(viii) [Séc. XVII] [...] esperando que em uma causa tão pia, tão justa, e de tanta glória de Deus e do Reino, lhe não faltará com muito especial atenção o patrocínio e amparo de V. Ex.a, como eu the tenho prometido e assegurado (CdP, séc. XVI)

(ix) [Séc. XVI] E já que assim o tenho ouvido, será bom dizerde-lo logo ao Padre, para que busque algum remédio (CdP, PE, séc. XVI)

(x) [Séc. XVI] Ama, já lh’eu tenho prometido. (CdP, Gil Vicente)

(xi) [Séc. XV] Oo senhora muyto he cousa de grande dóór andade toste \& ueeredes o uoso glorioso filho, o qual tem preso os judeus [...] (CdP, Contemplação de São Bernardo)

(xii) [Século XV] E faço fim do meu razoado encomendado de vós todo o que dito tenho e mais. (CdP, Crônica o Conde D. Pedro de Meneses)

(xiii) [Século XIV] Nõ lho podë demãdar ë juizo ca pois el ha feito uoto pera ficar ë religyõ. (CdP, Terceira Partida Alfonso X)

Essas ocorrências, principalmente (xi), por ser um verbo de mudança de estado, representa claramente a leitura resultativa através do evento tem preso, que é um resultado visível de uma ação anterior, posto em destaque no enunciado. Dessa forma, o evento é interpretado em sua fase, estado final, bem como se conclui que os sujeitos estejam presos no momento da enunciação. Além disso, podemos considerar que, nesses dados, o PPC poderia ser substituído pelo PPS, sem que o sentido de cada enunciado fosse alterado, ao menos no nível semântico, já que seria difícil afirmar algo sobre todos os nuances pragmáticos que se agregariam a esses enunciados históricos. Mais que isso, na sincronia, o PPS seria a forma de pretérito eleita possivelmente.

A seguir, mostra-se um contexto em que o PPC coocorre com o PPS através do mesmo verbo perdoar, que se destaca não somente por essa razão, mas pela clara leitura resultativa. O estado alcançado, ou seja, “o perdão de Deus”, é um fato (passado) colocado em evidência no presente da situação comunicativa. Ademais, é possível considerar que as diferenças aspectuais entre os dois pretéritos não se mostram claras, o que se configuraria como um contexto de sobreposição entre as duas formas verbais. No entanto, no primeiro exemplo, (a), o uso do PPC parece indicar uma tentativa de maior aproximação do fato anterior com a situação presente, por algum propósito discursivo-pragmático, o que, enfim, vai ao encontro da função resultativa-perfeita que parece caracterizar o surgimento das perífrases perfeitas nas línguas, segundo Squartini (1998). Dito de outra forma, a partir de Squartini e Bertinetto (2000), as formas compostas nas línguas românicas podem ter emergido com a função de reintroduzir um paradigma evidentemente perfeito.

(20) E o abbade Panunçio foy hu ella jazia e disse-lhe: - Perdoado te tem (a) Deos os teus pecados [...] E o abade lhe disse: - não te perdoou (b) Deus pela tua peen- 
dença, mas pelo teu arrependimento. E ella nom viveo mais XV días. E o abbade vyo hyr a sua alma pera o çeeo cõ gram cõpanha d'angos que faziam grande allegria cõ ella. O Senhor Deos que a ella perdoou (c) os sseus pecados. (CIPM, CdP, séc. XIII ou XIV, Vida de Santos de um Manuscrito Alcobacense)

Adicionalmente, trazemos alguns dados mais recentes que podem ilustrar a leitura universal ainda. Observe-se que o PPS poderia ser empregado nesses usos sem haver uma perda relevante de sentido, pois, mesmo que o PPS marque o aspecto perfectivo, o advérbio de quantificação universal (sempre) imprime que a situação perdurou no tempo, embora desligada, isto é, não inscrita no momento de fala.

(21) E de fora da leira para além, a terra é limpa, como tem estado sempre [...] (CdP, PE, séc. XX)

(22) Eu tenho sido sempre um observador de quando vejo um bicho, inspeccioná-lo. (CdP, PE, séc. XX)

Cabe sublinhar, através da intepretação desses dois últimos enunciados, que a presença do PPC permite a implicatura de que o evento poderá se repetir no tempo. Portanto, a presença de certos verbos télicos, como morrer e quebrar, dificilmente se associa com o PPC, como de fato verificamos em nossa investigação.

Soma-se a essa discussão um último dado do século XX e do $\mathrm{PB}$, em que o emprego do PPC chama a atenção por refletir um pouco alguns dos seus usos na diacronia, inclusive de modo similar às ocorrências mostradas nesta seção, no que concerne ao ponto em que o falante parece situar o evento tenho feito como anterior ao momento de fala.

(23) No correio lá perto onde eu trabalho, o rapaz me explicou que se colocar até oito horas da manhã - é recolhida e embarcada às oito horas mesmo da manhã, então, eu já tenho feito experiência nesse sentido, eu coloco a carta cedinho - e: na no dia - quando é no outro dia de manha a carta já é entregue [...] (CdP, PB, séc. XX)

Para concluir, além desses aspectos observados, consideramos que merece ser investigada em futuras análises mais qualitativas, a composição dos diferentes contextos discursivos em que se localiza PPC no português medieval - em quais gêneros de textos; 
enunciados avaliativos ou epistêmicos; trechos narrativos, episódicos ou genéricos. Um estudo que buscasse investigar esses fatores poderia identificar em quais contextos e situações PPC e PPS poderiam se sobrepor, bem como em quais enunciados o PPC surgiu e se estabeleceu com maior frequência na história da língua.

\section{A expressão da pluralidade do PPC em seus usos e funções em contextos discursivos: da semântica à pragmática}

Nesta subseção final, apresentamos uma quantificação geral dos verbos que ocorreram mais frequentemente com as formas compostas analisadas, a partir de uma distribuição do aspecto em termos de classes de verbos e Aktionsart, considerando-se dessa forma mais o conteúdo lexical verbal do que a interpretação de todo o predicado. O propósito desta análise mais qualitativa é, essencialmente, relacionar a presença de alguns verbos à realização das leituras descritas anteriormente e, em seguida, apontar outras funções do PPC, além da expressão dos valores semânticos já tratados. Isso porque as leituras identificadas nos usos do PPC se associam muito a determinadas classes verbais, seja no que diz respeito ao aspecto lexical ou ainda ao próprio significado do item verbal, como seriam os casos dos verbos de cognição e percepção direta.

Inicialmente, tratamos novamente da semântica do PPC, só que de uma forma mais específica para, então, correlacionarmos os seus valores em outros domínios, a partir da análise de alguns enunciados.

Ilari (2001) propõe uma analogia direta entre o pretérito composto e alguns quantificadores adverbiais, como muito, por exemplo. Da mesma forma que essas expressões transitam entre nomes massivos e contáveis, o PPC interage com os predicados télicos, que seriam similares aos nomes discretos ou contáveis, de um lado, e com os estativos ou semelfactivos, que se equiparariam aos não contáveis ou massivos, de outro. Os dois grupos (nomes contáveis ou não) reagem igualmente à soma quando estão na presença de um quantificador, como em "muita água", "muitos livros". Do mesmo modo que muito, então, o PPC interfere, caracteriza (sendo também caracterizado) de forma diferente o predicado (télico ou não) em que transita, embora expresse sempre a ideia única de soma, tanto dos valores incontáveis (no caso de predicados estativos) quanto dos contáveis (nos télicos) (ILARI, 2001, p. 20-22).

Dito de outro modo, só seria possível usar o PPC no português atual quando essa ideia de soma ou pluralidade pudesse ser implicada na interpretação. Por exemplo, o PPC não transita (hoje) em sentenças como: "Já tenho quebrado a perna., "Ele tem comprado 
uma casa para viver o resto da vida., pois nesses exemplos ele não consegue operar nenhuma função de soma, em razão da singularidade de evento, assim como da baixa probabilidade de que ocorra repetição de suas instâncias ou subeventos, inclusive no futuro. Por outro lado, da mesma forma que muito opera com massivos, o PPC pode ser usado em sentenças como “Tenho ficado em casa,” porque a situação é interpretada em sua pluralidade, ou seja, como se o sujeito tivesse ficado em casa várias vezes, o que acarreta uma leitura durativa ao evento, que é interpretado como massivo - a soma de água + água será água. No caso dos verbos télicos, algum sintagma precisa estar no plural para que o PPC ocorra: “Tenho escrito livros sobre economia." Por conseguinte, mesmo que o seu valor seja interpretado como duplo ou variável, através das leituras durativa ou iterativa, na realidade, o PPC pode ser definido em termos de um significado (função) único, como se ele atuasse como um verdadeiro quantificador em cada predicado verbal.

Essa analogia, embora se trate de semântica pura, é interessante, já que permite compreender o PPC em termos de atuação e desdobrar essa expressão em outros domínios, como no âmbito discursivo-pragmático.

Dessa forma, em razão da expressão de soma, quantidade, repetição embutida no uso do PPC, há uma implicação de que o evento denotado perdure (de forma iterativa ou contínua) no tempo. Portanto, consideramos possível afirmar que a ideia de repetição (de eventos ou subeventos) vinculada em seu uso pode se constituir numa razão adicional para o falante optar pelo seu emprego. Em outras palavras, aventamos a hipótese de que, além de sua função gramatical de marcar tempo-aspecto, o PPC pode ser empregado e escolhido para assinalar a soma, e a não singularidade de um evento, assim como a sua duração.

Esse efeito de repetição sinalizada pelo PPC, junto ao predicado verbal, pode imprimir uma maior força para a afirmação do falante, visto que sua declaração sustenta-se não em uma ocorrência singular do evento, mas em várias. Logo, uma análise discursivopragmática da forma pode revelar funções e papéis para o PPC em estratégias argumentativas, como no realce ou intensificação de um argumento. Nos exemplos a seguir, principalmente dos dois primeiros, é possível considerar que o uso do PPC também serve para o falante reiterar que o fato não ocorreu uma única vez e que esse evento esteja distante do momento de fala.

(24) Sr. João nunca os viu? - Vi, vi, tenho visto muitos. Olhe que fazem coisas que, fora a alma, já se sabe. (CdP, PB, séc. XX) 
(25) Rodrigo Maia elogia Moro: “fez e tem feito política”. Presidente da Câmara afirmou que o ministro da Justiça tem demonstrado capacidade política maior do que de outros ministros. (O Estadão, jornal, maio, 2019)

(26) Para que é que você está com essas coisas? Nós demo-nos sempre bem... Que diabo! Tenho sido sempre seu amigo, Américo. (CdP, PE, séc. XX)

Os enunciados (24) e (25) destacam-se pela presença do PPS junto ao PPC, sendo que os dois pretéritos denotam um mesmo item verbal em cada caso. Assim, essas ocorrências são interessantes, pois podem servir para ilustrar a hipótese de que, além de atualizar, imprimir um valor aspectual distinto do PPS, a presença do PPC acaba realçando a pluralidade de ocorrências de um mesmo tipo. Explica-se. Por implicatura, é possível concluir que ambos os eventos "vi" e "fez" ocorreram uma única vez, mesmo essa informação não sendo dada; logo, o uso do PPC - da mesma forma que a presença de "muitos" em (24) - pode funcionar para cancelar essa implicatura, posto que indica que o evento denotado se repetiu no tempo. ${ }^{31}$

Em sua história de evolução, esse fator pragmático pode ter contribuído para o PPC ter se especializado semanticamente nessa direção. Inicialmente, o PPC era uma forma de pretérito recorrentemente utilizada com advérbios, como muitos, vários, por exemplo, que indicavam essa pluralidade através de quantificação nominal, até o momento em que o PPC sozinho passou a ser utilizado com um recurso para expressar essa mesma função. A partir do século XVIII, sobretudo nos séculos XIX e XX, como pode ser visto no quatro 1 adiante, esse valor pluracional carregado pelo PPC altera-se em predicados não télicos e se reflete num valor durativo, haja vista sua associação crescente a verbos de estado. Assim, somado ao processo de mudança semântica proposto em Becker (2016), o fator de natureza pragmática, refletido através da intenção do falante em realçar uma leitura de pluralidade, pode twe contribuído na forma em que o PPC passou de um valor aspectual inicial não durativo, a partir da leitura resultativa, a um valor iterativo e durativo que o caracteriza atualmente.

Cabe observar, contudo, que essas funções atrelam-se muito ao tipo de modalidade proposicional e enunciado. Em contextos avaliativos e de discurso direto, por exemplo, elas podem se sobressair, como em (24), (25) e (26), ao passo que em situações episódicas, narrativas, como em: "Ele disse que tem dormido mais cedo", o valor quantificacional

\footnotetext{
${ }^{31}$ Por último, na ocorrência (26), o valor durativo do PPC também pode estar relacionado a uma estratégia de ênfase dada a uma situação que se estendeu no tempo.
} 
do PPC não tem como se associar a um ofício argumentativo, como parte de um possível estratégia de intensificação através da pluralidade embutida em seu uso.

Em seguida, apresentamos um quadro que contém alguns dos verbos mais frequentes encontrados na amostra investigada, os quais estão distribuídos de acordo com o aspecto lexical. O propósito principal dessa ilustração é mostrar que o uso do PPC associado aos verbos de estado foi um processo crescente ao longo dos séculos, o que significa que a leitura durativa foi cada vez mais se tornando recorrente, principalmente a partir do século XVIII, sendo que, nos últimos séculos, XIX e XX, foi a mais frequente e pode ser sido o fator final e decisivo para a caracterização do PPC contemporâneo como uma forma de perfeito iterativo ou pluracional, seguindo o enquadramento definido por Harris (1982) e utilizado por Squartini e Bertinetto (2000).

Quadro 1. Ocorrências de verbos de diferentes classes a partir do $\mathrm{CdP}^{32}$

O PPC e itens verbais mais frequentes num gradiente aspectual -télico _ +télico ${ }^{33}$

\begin{tabular}{|c|c|c|c|c|c|}
\hline & $\begin{array}{c}\text { Séc. XIV, XV, } \\
\text { XVI }\end{array}$ & $\begin{array}{l}\text { Séc. } \\
\text { XVII }\end{array}$ & $\begin{array}{l}\text { Séc. } \\
\text { XVIII }\end{array}$ & $\begin{array}{c}\text { Séc. XIX- } \\
\text { XX }\end{array}$ & Total \\
\hline 1.Tenho sido & - & - & 7 & 84 & 91 \\
\hline 1.Tem sido & - & 34 & 35 & 1601 & 1636 \\
\hline 2.Tem havido & - & 15 & 21 & 169 & 205 \\
\hline 3.Tem acontecido & 2 & 5 & 1 & 71 & 79 \\
\hline 4. Tenho pensado & - & - & - & 44 & 44 \\
\hline 4. Tem pensado & - & - & - & 7 & 7 \\
\hline 5.Tenho passado & 2 & 6 & 5 & 53 & 64 \\
\hline 5. Tem passado & 6 & 19 & 3 & 149 & 177 \\
\hline 6. Tenho andado & 1 & - & - & 49 & 50 \\
\hline 6. Tem andado & 2 & - & 1 & 58 & 59 \\
\hline 7. Tem mostrado & 10 & 26 & 12 & 50 & 87 \\
\hline 8.Tenho tido & - & 2 & 9 & 87 & 98 \\
\hline 8. Tem tido & - & 3 & 8 & 191 & 202 \\
\hline 9. Tenho ouvido & 8 & 14 & 8 & 79 & 109 \\
\hline 9. Tem ouvido & 2 & - & 1 & 15 & 18 \\
\hline 10. Tenho visto & 12 & 19 & 22 & 176 & 229 \\
\hline 10. Tem visto & 8 & 20 & 21 & 68 & 117 \\
\hline 11. Tenho dito & 68 & 85 & 18 & 107 & 288 \\
\hline 11. Tem dito & 9 & 18 & 6 & 76 & 109 \\
\hline 12. Tenho cuidado & 3 & 5 & - & 1 & 9 \\
\hline 12. Tem cuidado & 29 & 23 & 10 & 27 & 89 \\
\hline
\end{tabular}

33 Cabe observar que os dados em que o verbo auxiliar da construção composta era "haver" (ou "ser"), muito comuns até o século XVII, foram descartados da análise, em razão da recorrente dificuldade em se identificar a forma "he" como sendo do verbo "ser" ou "haver". 


\begin{tabular}{c|c|c|c|c|c}
\hline 13. Tenho trabalhado & - & 2 & 1 & 19 & 22 \\
\hline 13. Tem trabalhado & - & 5 & 1 & 17 & 23 \\
\hline 14. Tenho lido & - & 4 & 6 & 48 & 58 \\
\hline 14. Tem lido & - & - & 1 & 19 & 20 \\
\hline 15. Tenho dado & 7 & 27 & 11 & 23 & 68 \\
\hline 15. Tem dado & 45 & 59 & 27 & 179 & 318 \\
\hline 16. Tenho escrito & 11 & 30 & 4 & 17 & 62 \\
\hline 16. Tem escrito & 5 & 14 & 2 & 45 & 66 \\
\hline 17. Tenho feito & 11 & 24 & 20 & 115 & 170 \\
\hline 17. Tem feito & 70 & 92 & 51 & 364 & 577 \\
\hline
\end{tabular}

Assim, chama a atenção a forte ocorrência do PPC no que concerne ao item verbal "ser" e de alguns outros verbos de estado. Por conseguinte, podemos considerar que a leitura durativa se mostra muito representativa na semântica do PPC do português contemporâneo (séculos XIX e XX). Além disso, destaca-se a frequência com que "tem sido", "tenho pensado", e "tenho andado" (na ampla maioria dos dados com sentido estativo) cresceu ao longo dos séculos.

Por outro lado, verbos como "escrever" e "fazer", que podem compor predicados télicos, foram recorrentes desde os séculos XV e XVII, em que se identificava principalmente a leitura resultativa. De modo similar, "tenho dito" é a construção mais frequente, junto com "tem feito", no início do processo de evolução do PPC, possivelmente em razão de sua atuação (comunicativa) como um ato que poderia se configurar como performativo, e assim imprimir um valor vinculante à informação declarada - dessa forma, relevante para a situação corrente.

Outrossim, é possível observar uma considerável frequência dos verbos de percepção direta associados ao PPC, sobretudo “ver”, que aventamos representar uma interessante função discursiva para a construção, de ao mesmo tempo evidenciar a fonte real de informação verídica e a recorrência (repetida) do evento declarado, como podemos observar no último enunciado:

(27) Tornaram-se, eles próprios, merecedores todos de uma CPI. No Executivo, você tem visto todos os dias, a bagunça de as informações contraditórias que o ministro e seus trapalhões distribuem a cada dia. (CdP, séc. XX)

Além disso, a partir da descrição mais estrutural acerca da leitura resultativa, com base em Kiparsky (2002), é possível compreender a inter-relação entre esses dois pontos 
observados, uma vez um evento com valor durativo não se encaixa numa interpretação resultativa, , em que o evento complexo é interpretado (pelo falante) no seu estado (fase) final, o que não pode ocorrer com um evento durativo, visto que ele possui uma só fase ${ }^{34}$.

Finalmente, ressaltamos, assim como Barbosa (2008) e Becker (2016), que a produtividade do PPC em português é muito baixa se comparada às outras formas de pretérito. Por exemplo, em apontamento com base no Corpus do Português (CdP), a forma vi apareceu 7325 vezes, enquanto tenho visto apenas 229; já a forma escreveu ocorreu 1954, e tem escrito, só 45 vezes. Mais precisamente, em seu estudo, Barbosa (2008) encontrou a porcentagem de 53\% de ocorrência do PPS e de 0,6\% do PPC, com base numa amostra de 48 mil ocorrências de pretérito de variados gêneros de prosa narrativa do século XX.

Portanto, considerando a forte representatividade do pretérito simples em português e às leituras diacrônicas perdidas pelo PPC em sua trajetória histórica como fatores determinantes para os restritos contextos de uso e especializações semânticas do PPC contemporâneo.

\section{Considerações Finais}

Neste estudo, buscamos analisar a expressão do PPC em sua dimensão de natureza mais semântica, a partir de leituras de pluralidade ou durativas que caracterizam o seu uso. Em um primeiro momento, descrevemos que as várias leituras obtidas pelo PPC ao longo de sua expressão histórica foram decisivas para concretizar uma semântica nos limites da pluracionalidade, seguindo as análises de Becker $(2016,2020)$. Essas leituras teriam afastado o PPC de uma trajetória em direção a uma função perfeita, no sentido de marcar a relevância atual de um evento anterior, ou ainda perfectiva, em que uma situação linguística de maior competição com o PPS poderia ter sido concretizada, de modo similar ao que teria ocorrido em outras línguas românicas. No entanto, indicamos também que, em alguns dos seus usos anteriores, o PPC alcançou valores que se sobrepuseram à expressão do PPS, embora tenham sido reduzidos a usos marginais até desaparecerem, no século XX, também em consonância com os resultados de Barbosa (2008) e Becker (2016).

Como contribuição da análise, destacamos o apontamento de que o traço quantificacional que caracteriza o PPC contemporâneo indica que a leitura resultativa, assim como outras típicas do perfeito que entraram em competição com as leituras de pluralidade, ficaram restritas a seu uso histórico. Como um fator decisivo para o destino do

\footnotetext{
${ }^{34}$ Um evento durativo é verdadeiro em um intervalo $x$ e, como consequência, terá de ser verdadeiro em cada subintervalo de $x$. Assim, sua estrutura é distinta de um evento complexo télico $y$, que demanda uma mudança de estado, que poderá se apresentar de forma distinta em cada subintervalo ou fase de $y$.
} 
PPC, assinalamos que a crescente recorrência da leitura durativa, principalmente a partir do século XVIII, foi o componente final que restringiu o PPC a um perfeito de persistência e iteração, conforme a definição de Harris (1982). Como consequência, as leituras de pluralidade fixadas, que se associam a seus usos atuais, caracterizam a expressão do PPC como semelhante à de outros quantificadores adverbiais, que marcam a repetição de um evento, seguindo a analogia proposta em Ilari (2001). Com essa função, o PPC transita entre predicados estativos ou télicos, promovendo a intepretação de um evento como durativo ou iterativo, respectivamente. Ademais, a partir desses valores que marcam a sua pluracionalidade, aventamos que outras funções discursivas podem ser desdobradas em seu uso, como a de marcar que um evento, em suas instâncias, se repete ou se prolonga de maneira proposital pelo falante, que pode buscar intensificar um determinado conteúdo proposicional, ou melhor, um fato declarado ou uma opinião defendida.

Por fim, a análise confirmou também que, além das propriedades estruturais, as leituras que envolvem o perfeito esbarram e se concretizam também a partir da inter-relação com sentidos convencionalizados em cada língua diacronicamente. Essa seria uma explicação possível para dois recorrentes fenômenos observados na sincronia: a polissemia (nas leituras) do perfeito em uma mesma língua e a diversidade interlinguística para a expressão dessa categoria.

Sugerimos pesquisas futuras que busquem discutir e caracterizar de modo mais descritivo e com mais detalhes potenciais contextos de competição e variação, em que os dois pretéritos possam ser intercambiáveis na diacronia, tanto numa investigação mais qualitativa quanto quantitativa de dados, e que busquem a análise de fatores no âmbito discursivo-pragmático. Este estudo ateve-se mais à descrição da semântica particular do pretérito perfeito composto e, nesse percurso, apontou, embora não como um objetivo central, possíveis motivações para o seu afastamento, em termos de valores semânticos, em relação à expressão tempo-aspectual do pretérito perfeito simples.

\section{Referências}

ADAMS, James. Social variation and the Latin Language: aspects of verbal morphology and syntax. Cambridge: Cambridge University Press, 2013.

AMARAL, Patricia; HOWE, Chad. Nominal and verbal plurality in the diachrony of the Portuguese present perfect. In: HOFHERR, Patricia Cabredo; LACA, Brenda (Ed.). Verbal plurality and distributivity. Berlin: De Gruyter, 2008.

BARBOSA, Juliana Bertucci. Estudo diacrônico do pretérito perfeito no português do Brasil. In: COSTA, Daniel Soares da (Ed.). Pesquisas linguísticas pautadas em corpora. São 
Paulo: Editora UNESP, 2014.

BARBOSA, Juliana Bertucci. Tenho feito / fiz a tese: uma proposta de caracterização do pretérito perfeito no português. 2008. 280 f. Tese (Doutorado em Linguística e Língua Portuguesa) - Faculdade de Ciências e Letras, Universidade Estadual Paulista, Araraquara, 2008.

BECKER, Martin. O PPC na história do Português do Brasil. In. História Semântica do Português do Brasil. ILARI, Rodolfo; BASSO, Renato (comp.). São Paulo: Contexto, 2020.

BECKER, Martin. O Pretérito Perfeito Composto em diacronia: uma evolução perfeita? Estudos de linguística Galega, v. 8, p. 25-43, 2016.

BITTENCOURT, Diana Reis de. O domínio do futuro do subjuntivo em português: entre temporalidade e modalidade. 2014. 344 f. Tese. (Doutorado em Linguística) - Programa de Pós-graduação em Linguística, UFSC, Florianópolis, 2014.

BUENO, Francisco. A formação histórica da língua portuguesa. Rio de Janeiro: Editora Acadêmica, 1958.

BULLA, Beatriz. Rodrigo Maia Elogia Moro: Faz e Tem Feito Política. O Estado De S. Paulo. São Paulo, 13 de maio de 2019. Disponível em: https://politica.estadao.com.br/ noticias/geral,rodrigo-maia-elogia-moro-fez-e-tem-feito-politica,70002827310. Acesso em: 13 de maio de 2019.

BYBEE, Joan.; PERKINS, Revere.; PAGLIUCA, William. The evolution of Grammar: tense, aspect, and modality in the languages of the world. London: The University of Chicago Press, 1994.

COAN, Márluce. As categorias Tempo, Aspecto, Modalidade e Referência na significação dos pretéritos mais-que-perfeito e perfeito: correlação entre função(ões)-forma(s) em tempo real e aparente. 2003. 233 f. Tese. (Doutorado em Linguística) - Programa de Pós-graduação em Linguística, UFSC, Florianópolis, 2003.

COMRIE, Bernard. Aspect. Cambridge: Cambridge University Press, 1976.

DAVIES, Mark; FERREIRA, Michael. O Corpus do Português: 45 million words, 1300s-1900s. Brigham Young University: Provo-UT, 2006. Disponível em: http://www. corpusdoportugues.org. Acesso em: 10 de abril de 2020.

HARRIS, Martin. The 'past simple' and the 'present perfect' in Romance. In. VINCENT, Nigel; HARRIS, Martin (Ed.). Studies in the Romance Verb. London: Croom Helm, 1982.

GÖRSKI, Edair Maria. Emergência de dar pra / de no domínio funcional da auxiliarização. Fórum Linguístico, Florianópolis, v. 17, n. 1, p. 4342-4356, abr. 2020.

GÖRSKI, Edair Maria et al. Mudança em fenômenos discursivos via variação e gramaticalização: o papel dos fatores sociais. Estudos Linguísticos, São Paulo, v. 32, p, 1-5, 2002.

ILARI, Rodolfo. Notas para uma semântica do passado composto em português. Revista Letras, Curitiba, n. 55, p. 129-152, 2001. 
KLEIN, Wolfgang. The present perfect puzzle. Language, Washington, DC, v. 68, n. 3, p. 525-552, 1992.

KIPARSKY, Paul. Event Structure and the perfect. In: BEAVER, David I. et al. (Ed.). The Constructions of Meaning. Stanford: CSLI Publications, 2002.

KIPARSKY, Paul. Blocking and periphrasis in inflectional paradigms. In: BOOIJ, Geert; MARLE, Jaap van. Yearbook of Morphology. Springer: New York, 2005.

LACA, Brenda. Perfect semantics: how universal are Ibero-American present perfects? In: HISPANIC LINGUISTICS SYMPOSIUM, 12., 2008, Quebec. Proceedings [...] Somerville: Cascadilla Proceedings Project, 2010.p. 1-16.

LACA, Brenda; CARVALHO, Sandra de; CABREDO-HOFHER, Patricia; When Perfect means "Plural": The present perfect in Northeastern Brazilian Portuguese. In: CABREDO-HOFHERR, Patricia; LACA, Brenda (org.) Layers of aspect. Stanford: CSLI Publications, 2010.

OLIVEIRA, Leandra Cristina de. Estágio de gramaticalização do pretérito perfeito composto no espanhol escrito de sete capitais hispano-falantes. 2010. $270 \mathrm{f}$. Tese (Doutorado em Linguística) - Programa de Pós-Graduação em Linguística, UFSC, Florianópolis, 2010.

PAIVA BOLÉO, Manuel. O perfeito e o pretérito em português em confronto com as outras línguas românicas, en Cursos e Conferências, Vol. VI, Suplemento ao vol. XIII do Boletim da Biblioteca da Universidade. Coimbra: Biblioteca da Universidade, 124-266, 1936.

PERINI, Mário. Gramática descritiva do português brasileiro. Petrópolis: Vozes, 2016.

PINKSTER, Harm. Estrategy and chronology of future and perfect tense auxiliaries in Latin. In: HARRIS, Martin; RAMAT, Paolo (Ed.). Historical Development of Auxiliaries. Berlin: Mouton de Gruyter, 1987.

SQUARTINI, Mario; BERTINETTO, Pier Marco. The Simple and Compound Past in Romance Languages. In: DAHL, Östen (Ed.). Tense and Aspect in the Languages of Europe. Berlin: De Gruyter, 2000.

SQUARTINI, Mario. Extragrammatical Expression of Information Source. In. AIKHENVALD, Alexandra I. The Oxford Handbook of Evidentiality. Oxford: Oxford University Press, 2018.

SQUARTINI, Mario. Verbal Periphrases in Romance: aspect, actionality, and grammaticalization. New York: Mouton de Gruyter, 2008.

TRAVAGLIA, Luis. O aspecto verbal no português: a categoria e sua expressão. 3. ed. Uberlândia: Universidade Federal de Uberlândia, 1994 [1981].

VALLE, Carla Regina Martins. Multifuncionalidade, mudança e variação de marcadores discursivos derivados de verbos cognitivos: forças semântico-pragmáticas, estilísticas e identitárias em competição. 2014. 415 f. Tese (Doutorado em Linguística) - Programa de Pós-Graduação em Linguística, UFSC, Florianópolis, 2014. 
VARSUL. Projeto Variação linguística na Região Sul do Brasil. Disponível em: http:// varsul.org.br. Acesso em: 1 maio de 2020.

VENDLER, Zeno. Linguistics in philosophy. Ithaca: Cornell University Press, 1967.

VIANA, Aniceto R. Gonçalves. Le portugais: phonétique et phonologie, morphologie, textes... Leipzig: Teubner, 1901.

WEINREICH, Uriel; LABOV, William; HERZOG, Marvin. Fundamentos empíricos para uma teoria da mudança linguística. Trad.: Marcos Bagno; revisão técnica: Carlos Alberto Faraco. São Paulo: Parábola, 2006 [1968]. 